\title{
Education and Labor Market Outcomes in Korea
}

\author{
Lan Joo ${ }^{1}$ \\ ${ }^{1}$ Graduate School of Education and Human Development, The George Washington University, Washington D.C., \\ USA
}

Correspondence: Lan Joo, Graduate School of Education and Human Development, The George Washington University, Washington D.C., USA. Tel: 1-571-337-7117. E-mail: lanjoolan@yahoo.com

Received: December 14, 2017

Accepted: January 29, 2018

Online Published: May 29, 2018

doi:10.5539/ies.v11n6p145

URL: https://doi.org/10.5539/ies.v11n6p145

\begin{abstract}
The study examined the prevailing assumption of education's role in labor market outcomes using samples from Korea's young adult population. KEEP, collected annually by KRIVET since 2004, includes an initial sample in 2004 of 12th graders from both general and vocational high schools; the sample size reflected a total of 2000 students for each school type. In 2006, a similar sampling was taken with 11th graders from special-purposed high schools for study; the sample size reflected a total of 600 students. In this study, the respondents' income-, social origin-, and education-related data were collected, and the multiple regression method was used to analyze the aforementioned data. The study examined the association between social origin and/or education and labor market outcomes, but given the prevalence of private tutoring in Korea, the study separated the examination of private tutoring recipients and compared their results to those of all general respondents. The findings revealed, against assumption, that the actual overall effect of education on income is weak, and there is no effect, especially, on private tutoring recipients. And if and when an association does exist, education appears to affect income negatively. On the other hand, social origin shows its statistical significance in its association with income across the groups; and among social origin components, the father's educational level and employment type appear to be predictors.
\end{abstract}

Keywords: education policy, education reform, income inequality, job, labor market outcomes, policy, private tutoring, social mobility, social origin, young adult employment

\section{Introduction}

Koreans' strong investment in their children's education may stem from their assumption that education determines labor market outcomes; thereby, education is viewed as a means of moving upward in terms of social mobility. In fact, in Korea, education did play an essential role in obtaining prestigious jobs, position promotions, and determining incomes (Kim, 2000), and it has continued to be regarded as a tool for moving upward in social mobility (Lee, 1993). Given such a prevailing assumption about the role of education in one's destination, there have been plenty of empirical studies (Chai, 2007; Hong \& Cho, 2011; Jo, 2006) examining the association between education and labor market outcomes. Furthermore, when considering the inequalities in labor market outcomes, current studies (Checchi, 2000; de Gregorio \& Lee, 2002; Psacharopoulo \& Woodhall, 1985) have emphasized the role of education, by stating that decreasing education inequalities could be a remedy for the inequality decline in labor market outcomes based on the assumption that the education system influences the labor market. However, it could be possible that education may play a limited role, with social origin serving as the sole impact or via education. Also, the inequalities in the labor market outcomes may have led to stratification within the education system rather than vice versa. Furthermore, it could be possible that different results from the effects of education and/or social origin may occur within diverse contexts (e.g. a country's labor market structure ad condition). Therefore, the purpose of this study is to examine the aforementioned assumptions, suggesting that the utility side of the role of education in increasing an individual's income and social status and decreasing income inequality within a population should be revisited. The study's findings are also expected to contribute to a research community concerned with social origin, education and destination.

\subsection{Context}

Koreans' unique educational fervor can be understood based on historical, cultural, and economic contexts. Historically, Koreans lived through highly dynamic episodes during the first half of the twentieth century: from the 
demolition of the Lee dynasty to the Japanese occupation and from the land reform to the Korean War, which all resulted in the destruction of the traditional class system. Without the traditional class structure in place, education became a means of selecting capable workers (Kim, 2000; Lee, 1993). Culturally, Koreans' primary value in life is achieving a high-ranking or prestigious position, and obtaining a degree from a prestigious university is a prerequisite for this positions. This value system stems from Korea's highly hierarchical society in which jobs and schools are all ranked (Kim, 2000, p. 109).

Economically, from the beginning of the 1960s, Korea's economic structure had changed: the ratio in secondary and tertiary industry was increased from $24.1 \%$ to $34.2 \%$ and $29.9 \%$ to $45.3 \%$ respectively. Accordingly, the labor market structure changed, which demanded a rapid increase in new occupations in the second and tertiary sectors (Lee, 2011, p. 243). Furthermore, with an acceleration of industrial development, jobs became more fragmented and hierarchical; for instance, high paying jobs and higher level (executive, manager), as well as semi-professional, positions emerged (Lee, 2011). Given the vacuum of traditional classes, these newly opened positions were filled with educated people regardless of their social origin. Therefore, the expansion of higher education was partly due to a rising demand for highly skilled workers in the labor market. For example, in 1975, the ratio of higher education graduates in the total workforce was $10 \%$, but it increased to $12.3 \%$ in 1988 , and again to $34.6 \%$ in 2008 (Lee, 2011, pp. 245). Throughout this time, Koreans observed and experienced the impact of education in relation to their social mobility; therefore, people came to strongly believe that education is the principal determining factor in their respective careers, as well as their children's future careers (Oh, 2000, p. 262).

\subsection{Relevant Scholarship}

\subsubsection{Social Origin and Labor Market Outcomes}

Some scholars (Bowles, 1971; Bowles \& Gintis, 1976; Collins, 1977, p. 79) asserted that social origin determines an individuals' destination, directly or indirectly, and the effect of social origin on education does not decrease. For an indirect effect, social class determines educational achievement; and education, in turn, determines occupation and income. The role of education in social mobility is to serve as a mechanism that reproduces the class structure. Empirical studies that examined the social origin effect on one's labor market outcomes include:

Breen and Whelan (1992) selected three cohorts of men, who entered the labor force between 1936 and 1982 in Ireland. They tested whether or not there had been a decreasing effect of social origin on social status while an increasing effect of education on social status occurred as the society moved towards meritocracy. The study found that the partial social origin effect remained constant, while the educational effect decreased overtime. In fact, higher levels of education qualifications became less valuable to the final cohort, because there had been an increase in the number of people obtaining higher educational qualifications across the three cohorts. With the nationally-represented large sample of Swedish employees, aged 25-45, in 1990, Erikson and Jonsson (1998) examined the effect of social origin on destination (class position and income). The authors found that even after controlling for education (level and type), social origin has an effect on both class position and income in Sweden, which is regarded as a relatively equal society. The most interesting finding was that, unlike class position which is influenced by social origin in the beginning of one's career, social origin's effect on income continues throughout the lifespan of one's career. Mastekaasa (2011) investigated the effect of social origin on income by using Norwegian birth registry databases that included a sample of all birth cohorts between 1955 and 1969. The author found that, unlike modernization theory's argument, the direct effect of social origin did not decrease over a period of time. In addition, the findings did not support an indirect effect of social origin via education but rather supported its direct effect. For its direct effect, the parents' level of education had a weak, negative effect on their children's income, while the parents' income had a strong, positive effect.

The empirical studies in Korea indicated that the reproduction of occupations between generations was low until the 1980 's, because it was a period of time when Korea's traditional class was vacuumed and new classes emerged (Jang, 2000, pp. 140-141). However, recent studies showed that Korea is no longer an open society. As for a direct impact, according to Jang, empirical studies (Hong, 1987; Hong \& Gu, 1993) showed that this reproduction of classes between generations occurred directly in Korea, particularly within the bourgeoisie class and among owners of large companies (Jang, 2000, p. 140). In many cases, generation transmission occurs more indirectly via education in Korea. Using Blau \& Duncan's model, Y. Kim and B. Kim (1999) found that education has been a determining factor contributing to occupational status. But simultaneously, there is a strong association between social origin, the father's level of education in particular, and educational achievement. The authors asserted that social origin has an indirect effect on occupational status via education, and education may play a role in reproducing class in Korea's current society. Furthermore, the authors pointed out, in comparison to Blau and Duncan's findings for the United States, that Korea showed a relatively lower impact of the father's occupational 
status on his child's occupational status. By employing the retrospective data collected from a randomly selected high school sample (22 years after 1971's graduation class), Han (1997) examined the effect of social origin and education on the respondents' current social status. The findings indicate that education has a strong effect on occupational status and income. On the other hand, social origin, particularly the father's educational level, had an indirect effect on occupational status and income via education. Yeo (2008) examined an association among social origin (father's SES), education, and income by applying the path analysis method to the Korean Welfare Panel data collected in 2006 ( $\left({ }^{\text {st }}\right.$ wave). The study's results indicated that the father's SES had more of an indirect impact on his child's income via education. However, the most interesting finding is that social origin, which had an indirect effect via education in Korea, now seems more inclined to influence income more directly among the younger generation. When comparing the social origin effect across age groups $(20-39 ; 40-49 ; 50-59)$, the author learned that the social origin's indirect effect via education decreased for age group 20-39 in comparison to the older groups, while its direct effect increased. In fact, education's effect decreased for the youngest of the groups. Based on KEEP data, Choi and Min (2015) analyzed the possibility of an association between origin and income. Referencing the initial sample of $9^{\text {th }}$ graders, their parents' background information (educational level and income) was collected from the $1^{\text {st }}$ wave, and their current income was collected between the $9^{\text {th }}$ and $10^{\text {th }}$ waves. The findings showed that the respondents whose parents had higher education levels and income received higher income in comparison to those whose parents had lower educational levels and income.

\subsubsection{Education and Labor Market Outcomes}

Technological functionalists, such as Treiman (1970), contend that education determines an individual's destination and a decrease in the effect of their social origin, because technological improvements during the industrialization period called for higher skills. And since education provides these necessary skills, it must expand to meet the demand. In turn, as a society becomes more achievement-based, individuals who possess the required skills and abilities will gain higher positions and incomes. Empirical studies supporting this view include:

In their pioneering work, Blau and Duncan (1967) focused on occupational mobility between generations and supported Parson's view on the new value system of universalism and achievement for social status attainment in industrial societies by stating that there is "a fundamental trend towards expanding universalism (which) characterizes industrial society" (p. 429). By examining the correlations among social origin, schooling (educational attainment), and social hierarchy (jobs, occupational careers, earnings, SES) throughout the entire course of the life cycle, Blau and Duncan found that schools provide students with adequate skills based upon their abilities, which determines their incomes and statuses as adults. Treiman and Yip (1989) also supported Parsons' view on the new value system of universalism and achievement for social status attainment in industrial societies. By examining cross-national data for 21 countries, they argued that greater social openness is found in industrial and meritocratic societies, because achievement determines one's status, while parental influence on education is not as profound. The decreasing effect of social origin on educational attainment occurs, because access to education is widely accessible via free education that is available to students of lower social origin. Simultaneously, the association between education and occupational positions increases in industrial societies.

Human capital theory (Becker, 1993; Shultz, 1961) also asserts that there are strong correlations among educational attainment, occupational status and income, because education provides necessary skills to increase productivity, which in turn induces rewards in the form of prestigious jobs and higher salaries. It is similar to technological functionalism where the importance of educational credentials in obtaining social positions increases as a society becomes more merit-based. Unlike technological functionalism, born from the field of sociology, which views education in social function, human capital theory evolved from the field of economic discipline that views the role of education in economic terms (Rubinson \& Ralph in Richardson (ed.), 1986).

Becker (1993) conceptualized the effect of education on income as a monetary gain from attending college by comparing returns and costs. Becker stated that there is a positive rate of return in increased levels of education, even after netting out direct and indirect costs of schooling and adjusting for better family backgrounds and the increased abilities of better educated people. However, empirical studies suggest that the private return on education may not always increase by the level of education. For example, as shown in Figure 1 (Psacharopoulos \& Patrinos, 2014), the return for higher education is not higher than that of secondary education in high-income countries. In fact, the higher return in higher education (in comparison to secondary education) only occurs among low-income countries. 


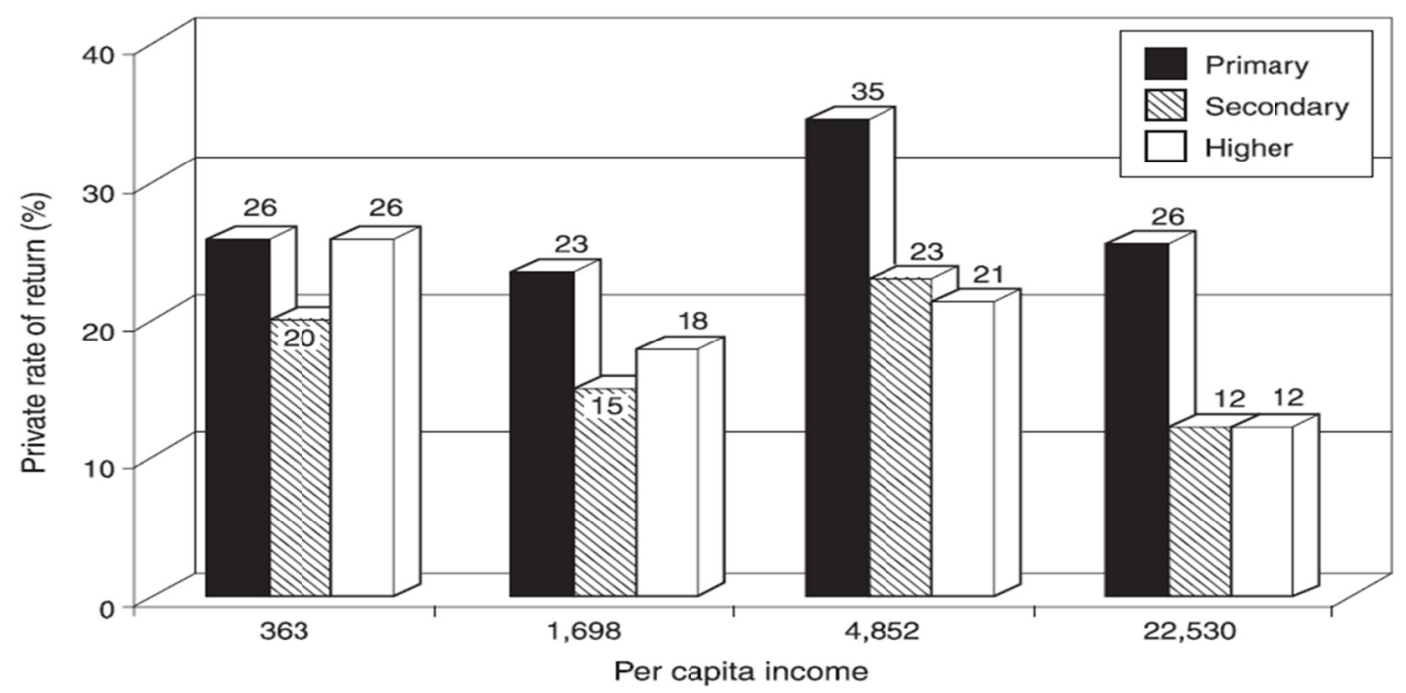

Figure 1. Returns on investing in education by a country's level of income

Source: Psacharopoulos and Patrinos, 2004, p.112, based on a raw return in education (\%) for 98 countries

Concerning education and income equality, according to the human capital theory, the distribution of incomes is determined by both the level and the distribution of education across the population, and this effect will either increase or decrease income inequality depending on the relative price of skills in a specific country. For instance, in a developing country with a lower-educated population, an increase in the number of educated people may initially raise income inequality; however, that inequality would decrease as the country develops (Asplund \& Barth, 2005). There are empirical studies investigating this association between education and income inequality. For example, Psacharopoulos and Woodhall (1985) and Checchi (2000) indicated that there is a negative correlation between the average level of education and income inequality, as a higher educational level could reduce income inequality. Conversely, there is a positive correlation between educational inequality and income inequality, because an unequal distribution of education across the population is likely to increase income inequality. Using OECD countries as an example, Checchi indicated how these countries' income inequalities have continued to increase despite increases to the length of the average school year, leading to his assertion that the rise in income inequality could be due to a rise in inequality in educational achievement across the population. Based on the panel data of a broad number of countries with five-year intervals between 1960 and 1990, De Gregorio and Lee (2002) also investigated the relationship between educational attainment and income distribution. The study's results showed that educational expansion could be negatively associated with income distribution; therefore, according to the authors, the combination of higher educational attainment with less educational inequality across the population could increase equality in income distribution.

In Korea's case, the wage differential by educational level has decreased since the mid-1980s, particularly between a two-year college and high school (Lee, 2011, p. 248). Furthermore, the wage premium for a two-year college or higher as opposed to high school has decreased. Figure 2 shows that it decreased dramatically between 1987 and 1994. 


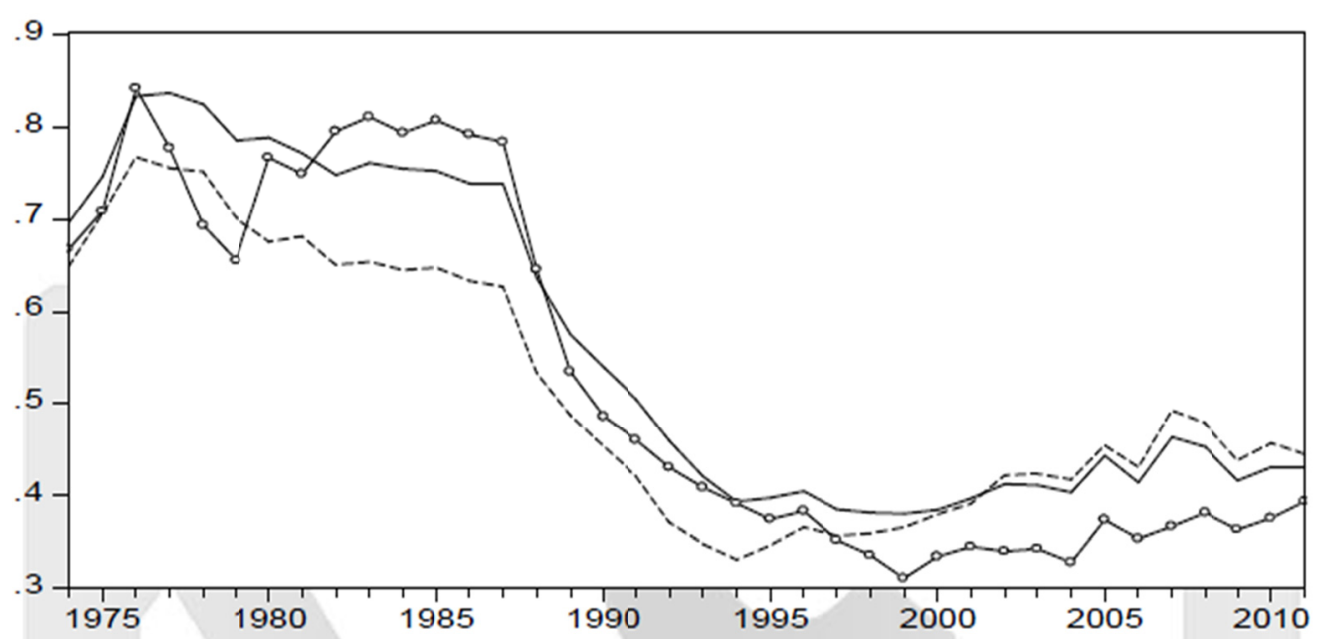

Figure 2. Wage premium for a two-year college or higher as opposed to high school between 1974 and 2011

Note. A line $=$ total labor force; a dotted line $=$ male; a line with a circle $=$ female

Source: Park, 2014, p. 481

Regarding education and income inequality, some empirical studies (Hong \& Cho, 2011; Jo, 2006) in Korea suggest that income inequality has decreased due to the expansion of higher education. However, other empirical studies reveal that during higher educational expansion, income inequality did not decrease, partly because of the stratification within the educational system. In fact, some scholars (Chai, 2007; Lee \& Kim, 2007; Park \& Kim, 2011) agreed that an individual's labor market outcomes (income and promotion) depended not only upon their educational level, but also the reputation, ranking, and the quality of the school they attended. For example, Lee and Kim (2007) asserted that throughout the expansion of higher education, four-year universities have become stratified based on name and quality. For this reason, the main wage determinant is not only educational levels, but also a school's name.

\subsubsection{Private Tutoring}

According to international empirical studies, demands for private tutoring have rapidly increased around the globe although the number of users and focus varies. Bray (2010) posited that although the degree and modality in private tutoring differs across the regions, it has become a global phenomenon due to an increasing competition within school systems. Concerning social origin and private tutoring, in Mauritian's case, Joynathsing et al. (1988) showed that 1st graders from the highest income group received private tutoring 7.5 times more than those from the low-income group (Bray, 2001, p. 364). In India, Chugh (2011) showed that among school dropouts in the slums of Delhi, India, $25.9 \%$ of respondents stated that the reason for dropout was the inability to pay high costs for private tutoring (Bray \& Lykins, 2012, p. 45).

In Korea, as of $2014,81.1 \%$ of primary level, $69.1 \%$ of lower secondary level, and $49.5 \%$ of upper secondary level students received private tutoring. Given this high participation in private tutoring, Korean scholars have been interested in examining factors, including parents' backgrounds that impact the rate of private tutoring and expenses. However, more scholars have recently become interested in the actual efficacy of private tutoring and its mediating role between household income and youth education (Park \& Do, 2005). For example, according to Park and Do, Yang's study (2003) found that parents with higher incomes and higher educational and occupational levels are more likely to increase the expenditure of private tutoring, because they have higher expectations for their children's education and at the same time, they are capable of paying for it. And by doing so, private tutoring increases their children's chances of entering top universities (Park \& Do, 2005). Based on the analysis of data from KEEP (2005), Lee et al. (2010) also found that students who were exposed more to private tutoring were less likely to attend a two- to three-year college as opposed to a four-year university.

In this article, I examined whether or not an association between social origin and/or education and labor market outcomes exists. Secondly, given the prevalence of private tutoring in Korea, I further investigated the same predictors and their associations with the labor market outcomes of those who received private tutoring. The study's methodology is non-experimental research, as the study utilized survey data that does not employ any manipulations. In other words, rather than examining the effect of a predictor variable on a dependent variable 
based on manipulation and its effect size, the study examines relationships and possible predictions between variables. In terms of method, statistical analysis was conducted by testing null hypotheses; and based on the measurement scale of a dependent variable, the study utilized multiple regression models among statistical methods. In order to do so, the variables were selected from theories (functionalism, human capital theory, and conflict theory) and pre-existing empirical studies.

\section{Data}

\subsection{Population and Samples}

The study utilized Korean Education and Employment Panel (KEEP) that is designed by the Korea Research Institute for Vocational Education Training (KRIVET). KEEP is longitudinal survey data that has been annually collected since 2004 (the first wave). The initial population is general and vocational high school students $\left(12^{\text {th }}\right.$ grade) in Korea, dating back to spring 2004, and special-purposed high school students (1 ${ }^{\text {th }}$ grade) in Korea, dating back to spring 2006. The schools include 1295 general high schools, 631 vocational high schools, and 40 special-purposed high schools that had more than 30 second grade students. The schools are in cities, districts, and towns across each region. Given that Korean students matriculate from grade to grade according to the calendar year, second year students from general and vocational high schools in 2003 that matriculated to the next level in 2004 and the second year special-purposed high school students in 2006 that subsequently matriculated to the next level in 2007 were included in the sample. The data was collected in 2004 for general and vocational high schools and was collected in 2007 for special purposed high schools. The initial samples were 2000 general, 2000 vocational, and 600 special-purposed high school students. The samples cover small schools in both rural and small towns.

\subsection{Sampling Procedures}

KRIVET utilized a stratified cluster sampling method with two stages. The first stage involved stratification: For general high schools, stratification occurred based on the region by dividing the population of students into subgroups of 15 regions (Seoul, six metropolitan cities and eight provinces; Jeju was excluded). For vocational high schools, stratification was created based on vocational types: technical high schools, commercial high schools, etc. During the second stage, 100 general and 100 vocational schools were randomly selected based on the sampling fraction used in each of the strata (region and vocational type) proportional to that of the total student population. The reason for using the sampling fraction was to increase the accuracy of equivalence among diverse parts of the region and vocational types, which in turn increases the statistical power for strata comparisons. Next, four classes were randomly selected from each of the schools, and five students were randomly selected from each class. As for special-purposed high schools, ten science and technology high schools were randomly selected out of a total of 16 schools with more than 30 second grade students. Out of a total of 24 schools with more than 30 second grade students, ten foreign language high schools were randomly selected based upon stratification of school types (private vs. public). Five classes were randomly selected from each school, and six students were randomly selected from each class.

\subsection{Data Collection}

KRIVET annually collects data via computer-assisted personal interviewing (CAPI). It utilizes a face-to-face method employing laptops in order to increase the respondent rate. Visser et al. (2000) stated that, "the face-to-face method increases response rates because a skilled interviewer can convince the respondents to participate and provide high-quality data...this method achieves much higher response rates, which reduces the potential for nonresponsive error." (p. 244). Any outliers that emerge during data collection are excluded. Before releasing the data, KRIVET also spends six months on data cleaning in order to detect and correct and/or remove inaccurate records, including outliers, from the database. The questionnaire is pre-set for four different types of responses based on a respondent's current position: (1) student enrolled in an undergraduate/graduate program; (2) employed; (3) unemployed; and (4) student preparing for the higher education entrance exam. Among the employed, the types of employment were divided into: (1) wage employee; (2) self-employed; and (3) unpaid family employee.

In this study, I collected data for wage employees, while the respondents who were not in the labor market and those identifying as self-employed and unpaid family employees were not included for the study's purpose. Income data was collected for a major job if the respondent held more than one job. Current income data was collected from the $10^{\text {th }}$ wave, and the first income was collected between the second and $10^{\text {th }}$ wave. The respondents' current educational level data was collected from the 10th wave but was traced to previous years if no information was found in the $10^{\text {th }}$. The respondents' parent's backgrounds and private tutoring information was collected from the Family Survey of the first wave for general and vocational high school students and the Family 
Survey of the fourth wave for special-purposed high school students.

As for missing data, I used the listwise deletion method, analyzing only the available data on each variable to test the hypotheses. I was unable to use a multiple imputation method for missing data, because independent variables were not continuous variables. The listwise method did not reduce the statistical power in this study, because there were still a considerable number of respondents. Furthermore, the reason for the reduced number of initial participants in this study was partly due to the nature of the panel data but also the current position segment, i.e. student, employed, and unemployed.

\subsection{Definition and Measurement of Variables}

\subsubsection{Social Origin}

Social origin is composed of five variables (father's employment type, father's educational level, mother's educational level, household assets, and household income). The selection of these variables is strictly based upon reviewing theoretical literature and empirical studies. Using KEEP, I have collected information on each variable, but the study modified the measurement of some of the variables for its purpose. The father's employment type included (1) Regular employee-reference group; (2) Irregular employee; (3) Employer; and (4) Self-employed. I included the father's employment type as a substitute for social class. Among the paid employee, a regular employee refers to someone who has an open-ended position, and the remainder of the paid employee refers to the irregular employee. Employer refers to someone who hires more than one paid employee, while self-employed means working without any paid employees. The parent's educational level was collapsed from nine levels to two levels, which are (1) High School or less-reference group and (2) two- to three-year College or higher. Household Income means the average monthly income of the household over one year from the time the survey was conducted. It is a continuous variable with an open-ended survey question type. Because the distribution of income was skewed, income data was transformed to the log of the data to restore symmetry. Household Assets refer to the total value of a respondent's family's financial assets when the survey was conducted. Assets includes the current value of their home and the market value of all real estate, such as residential homes, buildings, forests, fields, land, etc. It is a continuous variable with a multiple choice survey question type.

\subsubsection{Education}

Education is composed of three variables (tracking placement, current educational level, and private tutoring). I added private tutoring participation from a Korean-specific context which indicates that almost $70 \%$ of school enrollees receive some type of private tutoring. As for tracking placement, KRIVET designed the survey with three different types of high schools, General-reference group; Vocational; and Special-purposed high schools. The respondent's current educational level was collapsed from 12 levels to three levels, (1) High School; (2) two- to three-year College-reference group; and (3) four-year University or higher. If someone did not complete college, I included them in the high school level; and if someone did not complete university, I included them in the college level. Private tutoring participation was measured at a nominal scale, (1) Yes and (2) No-reference group. When examining the second research inquiry, I added private tutoring expenses. It refers to an average monthly payment incurred between September 2003 and February 2004 (during 11th grade). It is a continuous variable with an open-ended survey question type. Because the distribution of income was skewed, income data was transformed to the $\log$ of the data to restore symmetry.

\subsubsection{Labor Market Outcome}

Labor market outcome was measured by the respondent's income, which has been most commonly used in the existing empirical studies. The wage job includes both full- and part-time employment (more than 18 hours per week), except for university employment. A monthly income refers to net income and excludes health insurance and pension. It also excludes over-time payment and any incentives. It is a continuous variable with an open-ended survey question type. Because the distribution of income was skewed, income data was transformed to the log of the data to restore symmetry.

\subsection{Procedure}

The purpose of using the multiple regression analysis in this study is to conduct explanatory research that examines specified relationships. Rather than selecting all possible predictors (either by backward or forward elimination in exploratory research), I tested the overall association between the social origin and/or education and the labor market outcomes delineated in the two opposing theoretical views (functionalism and human capital theory vs. conflict theory). As for each component of social origin and education variables (predictors), I selected them from the existing empirical studies that examined the association between each predictor and the outcome variable. Then, I tested the social origin effect when education was controlled and tested education effect when social origin 
was controlled. The full model of both effects was tested as well. Thus, when $\mathrm{Y}$ is income, the equation is below:

Model 1: $Y=b_{0}+b_{1} x_{1}+b_{2} x_{2}+b_{3} x_{3}+b_{4} x_{4}+b_{5} x_{5}$

Model 2: $\mathrm{Y}_{=} b_{0}+b_{6} x_{6}+b_{7} x_{7}+b_{8} x_{8}$

Full Model: $Y_{=} b_{0}+b_{1} x_{1}+b_{2} x_{2}+b_{3} x_{3}+b_{4} x_{4}+b_{5} x_{5}+b_{6} x_{6}+b_{7} x_{7}+b_{8} x_{8}$

When $x_{1}$ is father's employment type, $x_{2}$ is father's educational level, $x_{3}$ is mother's educational level, $x_{4}$ is household income, $x_{5}$ is household assets, $\mathrm{x}_{6}$ is tracking placement, $\mathrm{x}_{7}$ is current educational level, $\mathrm{x}_{8}$ is private tutoring participation, $b_{0}$ is the constant intercept term, and $b_{1}, b_{2}, b_{3}, b_{4}, b_{5}, b_{6}, b_{7}, b_{8}$ is the regression coefficient for the corresponding independent variable.

The same regression models were used for the group of respondents who received private tutoring. In this case, $\mathrm{X}_{8}$ was private tutoring expenses.

\section{Results}

\subsection{Descriptive Statistics}

Table 1 depicts the respondents who remained in the $10^{\text {th }}$ wave as wage employees. The largest number of the father's employment type belongs to either regular employee $(N=622)$ or self-employed $(N=557) .22 .9 \%$ of the respondents' father's educational level is two- to three-year college or higher $(N=392)$, while $10.5 \%$ of mother's education level is two- to three-year college or higher $(N=190)$. The mean household income is 2752700 Won (equivalent to $\$ 2750.27)(M=257.27, S D=181.25)$. The mean expense for private tutoring per month is 328900 Won (equivalent to $\$ 320.89)(N=32.89, S D=31.35)$. The current educational level indicates that $59.7 \%$ of the respondents completed a two- to three-year college $(N=1,131)$, while $18.0 \%$ completed a four-year university or higher $(N=340)$. The mean of the current income is 172.67 Won $(\$ 1720.67)(M=172, S D=57.65)$.

Table 1. Descriptive Statistics

\begin{tabular}{|c|c|c|c|c|c|c|c|}
\hline & & $\mathrm{n}$ & $\%$ & M & $\mathrm{SD}$ & kurtosis & Skewness \\
\hline \multirow{15}{*}{ Region } & Seoul & 274 & 14.5 & & & & \\
\hline & Busan & 144 & 7.6 & & & & \\
\hline & Daegu & 113 & 6.0 & & & & \\
\hline & Incheon & 89 & 4.7 & & & & \\
\hline & Gwangju & 60 & 3.2 & & & & \\
\hline & Daejeon & 50 & 2.6 & & & & \\
\hline & Ulsan & 43 & 2.3 & & & & \\
\hline & Gyeonggi & 307 & 16.2 & & & & \\
\hline & Kangwon & 55 & 2.9 & & & & \\
\hline & Chungbuk & 94 & 5.0 & & & & \\
\hline & Chungnam & 93 & 4.9 & & & & \\
\hline & Jeonbuk & 129 & 6.8 & & & & \\
\hline & Jeonnam & 118 & 6.2 & & & & \\
\hline & Gyeongbuk & 205 & 10.8 & & & & \\
\hline & Gyeongnam & 120 & 6.3 & & & & \\
\hline \multirow{2}{*}{ Gender } & M & 1029 & 54.3 & & & & \\
\hline & $\mathrm{F}$ & 865 & 45.7 & & & & \\
\hline \multirow{4}{*}{$\begin{array}{c}\text { Father's } \\
\text { Employment } \\
\text { Type }\end{array}$} & Employer & 271 & 16.8 & & & & \\
\hline & RegEmployee & 622 & 38.5 & & & & \\
\hline & IrregEmployee & 166 & 10.3 & & & & \\
\hline & Self-employed & 557 & 34.5 & & & & \\
\hline Father's & $>=$ High School & 1322 & 77.1 & & & & \\
\hline Education & $=<$ College & 392 & 22.9 & & & & \\
\hline Mother's & $>=$ High School & 1612 & 89.5 & & & & \\
\hline Education & $=<$ College & 190 & 10.5 & & & & \\
\hline Household & & & & 275.27 & 181.25 & 12.13 & 2.45 \\
\hline $\ln ($ income $)$ & & & & 5.43 & 0.64 & 0.83 & -0.42 \\
\hline $\begin{array}{c}\text { Household } \\
\text { Assets }\end{array}$ & & & & 4.96 & 2.34 & -0.22 & 0.34 \\
\hline
\end{tabular}




\begin{tabular}{|c|c|c|c|c|c|c|c|}
\hline \multirow{2}{*}{ Private Tutoring } & No & 708 & 52.6 & & & & \\
\hline & Yes & 637 & 47.4 & & & & \\
\hline \multirow{2}{*}{$\begin{array}{l}\text { Private Tutoring } \\
\text { In(Expenses) }\end{array}$} & & & & 32.89 & 31.35 & 17.76 & 3.18 \\
\hline & & & & 3.09 & 1.00 & 0.98 & 0.78 \\
\hline \multirow{3}{*}{ Tracking } & Vocational & 884 & 46.7 & & & & \\
\hline & General & 903 & 47.7 & & & & \\
\hline & Special-purposed & 107 & 5.6 & & & & \\
\hline \multirow{3}{*}{$\begin{array}{c}\text { Educational } \\
\text { Level }\end{array}$} & High School & 423 & 22.3 & & & & \\
\hline & College & 1131 & 59.7 & & & & \\
\hline & $=<$ University & 340 & 18.0 & & & & \\
\hline First & & & & 118.41 & 63.79 & 21.58 & 2.39 \\
\hline In(income) & & & & 4.63 & 0.58 & 1.57 & -0.88 \\
\hline Current & & & & 172.67 & 57.65 & 17.92 & 1.16 \\
\hline $\ln$ (income) & & & & 5.09 & 0.39 & 4.86 & -2.40 \\
\hline
\end{tabular}

Note. Although the exchange rate is not a fixed rate, I calculated 1 USD equals 1000 Won for convenience

\subsection{To What Extent Do Differences in the Parents' Backgrounds and/or Education Predict Labor Market Outcomes?}

Table 2 shows that only social origin was statistically significant on the first income $(p<.001)$ (Model 1$)$. Among the components of social origin, the father's employment type, after controlling for the other four components, was statistically significantly associated with the first income $(p<.05)$ : The respondents whose fathers are employers earn higher than those whose fathers are regular employees. None of the educational variables showed a statistically significant association with the first income (Model 2). Social origin combined with education (Full Model) also did not show a statistically significant effect overall, but the father's education level showed a positive association with his child's income. Concerning whether the model fits the data, I tested R-squared, Breusch-Pagan (B-P) statistics, and Kolmogorov-Smirnov (K-S) statistics. R-squared was low $\left(R^{2}=.004\right)$, but two other Goodness-of-fit statistics indicated that the model fits the data. Also, each model's residual plot showed no pattern.

Table 2. Regression analysis for social origin and/or education predicting first income

\begin{tabular}{|c|c|c|c|c|c|c|}
\hline & \multicolumn{2}{|c|}{ Social Origin (Model 1) } & \multicolumn{2}{|c|}{ Education (Model 2) } & \multicolumn{2}{|c|}{$\begin{array}{c}\text { Social Origin and } \\
\text { Education (Full Model) }\end{array}$} \\
\hline & $\mathrm{B}$ & $\beta$ & $\mathrm{B}$ & $\beta$ & B & $\beta$ \\
\hline constant & 4.627 & & 4.597 & & 4.587 & \\
\hline \multicolumn{7}{|l|}{ Father's EmpType } \\
\hline Employer & .088 & $.054^{* *}$ & & & .043 & .027 \\
\hline Irregular Employee & .013 & .007 & & & .026 & .012 \\
\hline Self-employed & .021 & .017 & & & .006 & .005 \\
\hline Father's Education & .063 & .004 & & & .099 & $.069^{* *}$ \\
\hline Mother's Education & -.005 & -.003 & & & -.021 & -.010 \\
\hline $\ln$ (income) & -.006 & -.005 & & & .002 & .001 \\
\hline Assets & -.009 & -.036 & & & -.005 & -.018 \\
\hline \multicolumn{7}{|l|}{ Tracking Placement } \\
\hline Special & & & -.065 & -.020 & -.065 & -.017 \\
\hline Vocational & & & .056 & .047 & .049 & .035 \\
\hline \multicolumn{7}{|l|}{ Educational Level } \\
\hline High School & & & .033 & .002 & .034 & .046 \\
\hline$=<$ University & & & .003 & .002 & .055 & .003 \\
\hline Private Tutoring & & & -.020 & -.017 & -.022 & -.018 \\
\hline
\end{tabular}




\begin{tabular}{cccc}
\hline $\mathrm{D}-\mathrm{W}\left(\mathrm{d}_{\mathrm{U}}\right)$ & $1.977(1.934)$ & $1.991(1.927)$ & $1.976(1.930)$ \\
$\mathrm{R}^{2}$ & .004 & .004 & .007 \\
$\mathrm{~F}(\mathrm{p})$ & $1.226(7,2143)(\mathrm{p}=.000)$ & $1.500(5,1752)(\mathrm{p}=.187)$ & $.813(12,1442)(\mathrm{p}=.637)$ \\
$\mathrm{K}-\mathrm{S}$ & $.738(.304)$ & $.587(.336)$ & $.159(.394)$ \\
$\mathrm{B}-\mathrm{P}$ & $3.235(.862)$ & $5.235(.388)$ & $5.800(.926)$ \\
$N$ & 1882 & 1753 & 1443 \\
\hline
\end{tabular}

In contrast to the first income, social origin $(p<.001)$, education $(p<.001)$, and the full model $(p<.001)$ were found to be statistically significant on current income. However, the R-squared of each model was low. As shown in Table 3, the variance in the current income is explained by $2.1 \%$ of social origin $\left(\mathrm{R}^{2}=.021\right), 2.1 \%$ of education $\left(\mathrm{R}^{2}=.021\right)$, and $4.3 \%$ of the full model $\left(\mathrm{R}^{2}=.043\right)$. Among the components of the social origin variable (Model 1 ), the father's employment type and education were associated positively with current income. Among the components of the education variable (Model 2), the respondent's current educational level was statistically significant: In comparison to a college, high school was negatively associated with income $(p<.05)$, and university or higher was associated negatively with income $(p<.05)$. In other words, college graduates earn higher than both high school graduates and university or higher. Receiving private tutoring was associated positively with current income $(p<.05)$. When education and social origin variables were combined (the Full Model), the father's education $(p<.05)$ and the respondent's education $(p<.05)$ were found to be statistically significant. Other components' effects disappeared in the full model. Similar to Model 2, college graduates earned higher than both high school graduates and university or higher. The models' residual plots showed no pattern. Although the R-squared of each model was low, two other Goodness-of-fit statistics showed that the model fits the data.

Table 3. Regression analysis for social origin and/or education predicting current income

\begin{tabular}{|c|c|c|c|c|c|c|}
\hline & \multicolumn{2}{|c|}{ Social Origin (Model 1) } & \multicolumn{2}{|c|}{ Education (Model 2) } & \multicolumn{2}{|c|}{ Social Origin and Education (Full Model) } \\
\hline & $\mathrm{B}$ & $\beta$ & B & $\beta$ & $\mathrm{B}$ & $\beta$ \\
\hline constant & 4.842 & & 5.131 & & 4.821 & \\
\hline \multicolumn{7}{|l|}{ Father's EmpType } \\
\hline Employer & .077 & $.074^{* *}$ & & & .062 & .065 \\
\hline Irregular Employee & .080 & $.062^{* *}$ & & & .077 & .059 \\
\hline Self-employed & .019 & .023 & & & .002 & .003 \\
\hline Father's Education & .084 & $.094^{* *}$ & & & .071 & $.083^{* *}$ \\
\hline Mother's Education & -.035 & -.028 & & & .004 & .003 \\
\hline $\ln$ (income) & .035 & .049 & & & .048 & .067 \\
\hline asset & .004 & .021 & & & .001 & .006 \\
\hline \multicolumn{7}{|l|}{ Tracking Placement } \\
\hline Special & & & .007 & .004 & -.053 & -.027 \\
\hline Vocational & & & -.044 & -.060 & -.039 & -.053 \\
\hline \multicolumn{7}{|l|}{ Educational Level } \\
\hline High School & & & -.067 & $-.071^{* *}$ & -.106 & -.039 \\
\hline$=<$ University & & & -.093 & $-.088^{* *}$ & .035 & $-.101^{* *}$ \\
\hline Private Tutoring & & & .050 & $.069^{* *}$ & .035 & .048 \\
\hline $\mathrm{D}-\mathrm{W}\left(\mathrm{d}_{\mathrm{U}}\right)$ & \multicolumn{2}{|c|}{$1.934(1.919)$} & \multicolumn{2}{|c|}{$2.074(1.910)$} & \multicolumn{2}{|c|}{$1.954(1.918)$} \\
\hline $\mathrm{R}^{2}$ & \multicolumn{2}{|c|}{$.021(2.1 \%)$} & \multicolumn{2}{|c|}{$.021(2.1 \%)$} & \multicolumn{2}{|c|}{$.043(4.3 \%)$} \\
\hline$F(p)$ & \multicolumn{2}{|c|}{$3.863(7,1258)(\mathrm{p}=.000)$} & \multicolumn{2}{|c|}{$4.608(5,1087)(\mathrm{p}=.000)$} & \multicolumn{2}{|c|}{$3.415(12,912)(\mathrm{p}=.000)$} \\
\hline K-S & \multicolumn{2}{|c|}{$.341(.376)$} & \multicolumn{2}{|c|}{$.884(.270)$} & \multicolumn{2}{|c|}{$.473(.357)$} \\
\hline B-P & \multicolumn{2}{|c|}{$8.235(.312)$} & \multicolumn{2}{|c|}{$5.353(.374)$} & \multicolumn{2}{|c|}{$18.553(.100)$} \\
\hline$N$ & \multicolumn{2}{|c|}{1259} & \multicolumn{2}{|c|}{1088} & \multicolumn{2}{|c|}{913} \\
\hline
\end{tabular}


Based on the findings, there are several implications to highlight in regards to the association between education and income. First, the study's finding that education is only associated with later employment is inconsistent with conventional belief that education determines the time of one's labor market entry. For instance, Kim and Kim (1997) suggested that the first occupation is directly influenced by education (the educational level), and education, together with working experience, continually influences long-term career advancement (p. 157). However, as the finding indicates, in Korea, social origin, not education, determines the start of one's career and has a continual effect throughout its duration. This finding is rather consistent with the findings from Erikson and Jonsson's (1998) study that showed that social origin directly affects employees' incomes, not only at the start of their careers, but throughout.

Second, unlike previous studies, the findings indicate the minimal size of the effect of education: education explained $2.1 \%$ of income variance. That is minimal when compared to the findings from international studies. For example, by collecting the countries' study results which were conducted as a part of the Education and Wage Inequality in Europe project, Asplund and Barth (2005, p. 19) found that "the dispersion of education contributes something between 10 and $15 \%$ to the overall distribution of wages." However, another study indicates that the size of education's effect can be as low as $3 \%$. Based on a collective country panel data set covering five-year intervals over the period 1960 to 1995 for 94 countries, Checchi (2000, p. 21) concluded that "education explains between $3 \%$ and $16 \%$ of the dispersion in incomes, with the relative contribution of education being higher." The inconsistency in the effect size could be attributed to the age group under examination. This study was based on young adults' labor market outcomes, while the international studies were conducted using a working-age population. This inconsistency further implies that there could be a different size in the effect of education between a young adult population and a working-age population; therefore, educational and labor market policies targeting young adults should be developed differently from those of other age groups.

Third, the finding on a negative association between education and income is also inconsistent with conventional belief and previous studies (Chai, 2007; Lee, 2011) that the level of education is positively associated with income level. This inconsistency can be explained by the current labor market condition for young adults in Korea. Given highly competitive conditions, young adults with higher levels of education would rather continue their studies and spend more time on job preparation to acquire more desirable position, while working part-time. Conversely, their counterparts prefer to hold a permanent or full-time position immediately after graduation to avoid unemployment.

Finally, vocational track as opposed to general track is not statistically significantly associated with the labor market outcomes. This study compared the tracking effect across three tracking placements (vocational as opposed to general and special-purposed as opposed to general). The finding on the lack of the vocational track effect could be explained by the fact that Korean tracking systems are characterized by low enrollment in the vocational track. Furthermore, similar to their counterparts (general high school graduates), a high portion of Korean vocational high school graduates (approximately $40 \%$ of total graduates) advance into higher education, mostly in two- to three year-colleges.

\subsection{To What Extent Do Differences in the Parents' Backgrounds and/or Education Predict Labor Market Outcomes among Those Who Received Private Tutoring?}

The study investigated the same predictors and their associations with the income of those who received private tutoring in order to investigate any differences in these associations between the general population and private tutoring recipients.

Concerning the first income, the overall impact of social origin and/or education was not statistically significant. However, an individual variable showed significance. As shown in Table 4, the father's education, after controlling for other social origin variables, was associated positively with his child's first income $(p<.05)$. When social origin was combined with education, the father's education still remained statistically significant $(p<.05)$. Among education variables, university or higher (as opposed to two- to three-year college) were associated negatively with the first income. $(p<.05)$. When combined with social origin, university or higher (as opposed to two- to three-year college) still remained statistically significant $(p<.05)$. The $\mathrm{R}$-squared for each model was not high, but other Goodness-of-fit statistics indicated that the model fits the data. Also, the residual plot of each model showed no pattern. 
Table 4. Regression analysis for social origin and/or education predicting first income among those who received private tutoring

\begin{tabular}{|c|c|c|c|c|c|c|}
\hline & \multicolumn{2}{|c|}{ Social Origin (Model 1) } & \multicolumn{2}{|c|}{ Education (Model 2) } & \multicolumn{2}{|c|}{$\begin{array}{l}\text { Social Origin and Education } \\
\text { (Full Model) }\end{array}$} \\
\hline & $\mathrm{B}$ & $\beta$ & $\mathrm{B}$ & $\beta$ & $\mathrm{B}$ & $\beta$ \\
\hline Constant & 4.698 & & 4.598 & & 4.409 & \\
\hline \multicolumn{7}{|l|}{ Father's EmpType } \\
\hline Employer & 110 & .065 & & & .073 & .043 \\
\hline Irregular Employee & .005 & .002 & & & .035 & .012 \\
\hline Self-employed & .046 & .031 & & & .019 & .013 \\
\hline Father's Education & .180 & $.127^{* *}$ & & & .227 & $.159^{* *}$ \\
\hline Mother's Education & -.171 & -.094 & & & -.167 & -.088 \\
\hline $\ln ($ income $)$ & -.031 & -.023 & & & .028 & .020 \\
\hline Assets & -.002 & -.006 & & & -.006 & -.019 \\
\hline \multicolumn{7}{|l|}{ Tracking Placement } \\
\hline Special & & & -.110 & -.040 & -.097 & -.030 \\
\hline Vocational & & & .019 & .012 & .091 & .012 \\
\hline \multicolumn{7}{|l|}{ Educational Level } \\
\hline High School & & & .084 & .043 & .104 & .051 \\
\hline$=<$ University & & & .152 & $-.078 * *$ & .180 & $.095^{* *}$ \\
\hline Tutoring Expenses & & & -.014 & -.020 & -.016 & -.024 \\
\hline $\mathrm{D}-\mathrm{W}\left(\mathrm{d}_{\mathrm{U}}\right)$ & \multicolumn{2}{|c|}{$2.017(1.896)$} & \multicolumn{2}{|c|}{$2.065(1.891)$} & \multicolumn{2}{|c|}{$2.019(1.907)$} \\
\hline $\mathrm{R}^{2}$ & \multicolumn{2}{|c|}{.015} & \multicolumn{2}{|c|}{.008} & \multicolumn{2}{|c|}{.031} \\
\hline $\mathrm{F}(\mathrm{p})$ & \multicolumn{2}{|c|}{$1.473(7,705)(\mathrm{p}=.174)$} & \multicolumn{2}{|c|}{$1.078(5,699)(\mathrm{p}=.371)$} & \multicolumn{2}{|c|}{$1.582(12,592)(\mathrm{p}=.092)$} \\
\hline K-S & \multicolumn{2}{|c|}{$.937(.174)$} & \multicolumn{2}{|c|}{$.768(.297)$} & \multicolumn{2}{|c|}{$.647(.324)$} \\
\hline B-P & \multicolumn{2}{|c|}{$1.840(.175)$} & \multicolumn{2}{|c|}{$4.238(.516)$} & \multicolumn{2}{|c|}{$7.235(.842)$} \\
\hline$N$ & \multicolumn{2}{|c|}{706} & \multicolumn{2}{|c|}{700} & \multicolumn{2}{|c|}{593} \\
\hline
\end{tabular}

As shown in Table 5, the overall effect of social origin and/or education on current income was not found to be statistically significant. None of the individual variables among education showed statistical significance, but an individual variable of social origin did show statistical significance. Among the components of social origin variables (Model 1), the father's employment type, after controlling for four other social origin variables, was positively associated with current income $(p<.01)$, and when social origin was combined with education, the father's education was positively associated with income $(p<.05)$. The residual plot of each model showed no pattern. Although the R-squared was not high like other previous models, Goodness-of-fit statistics indicated that the model fits the data.

Table 5. Regression analysis for social origin and/or education predicting current income among those who received private tutoring

\begin{tabular}{|c|c|c|c|c|c|c|}
\hline & \multicolumn{2}{|c|}{ Social Origin (Model 1) } & \multicolumn{2}{|c|}{ Education (Model 2) } & \multicolumn{2}{|c|}{$\begin{array}{l}\text { Social Origin and Education } \\
\text { (Full Model) }\end{array}$} \\
\hline & $\mathrm{B}$ & $\beta$ & $\mathrm{B}$ & $\beta$ & $\mathrm{B}$ & $\beta$ \\
\hline constant & 5.013 & & 5.184 & & 4,930 & \\
\hline \multicolumn{7}{|l|}{ Father's EmpType } \\
\hline Employer & .105 & $.117^{*}$ & & & .088 & .101 \\
\hline Irregular Employee & .117 & .074 & & & .132 & .083 \\
\hline Self-employed & .048 & .063 & & & .077 & .103 \\
\hline Father's Education & .058 & .077 & & & .097 & $.132 * *$ \\
\hline Mother's Education & .031 & -.031 & & & .015 & .014 \\
\hline $\ln$ (income) & .000 & .000 & & & .026 & .037 \\
\hline asset & .010 & .061 & & & .010 & .059 \\
\hline \multicolumn{7}{|l|}{ Tracking Placement } \\
\hline Special & & & -.061 & -.048 & -.116 & -.078 \\
\hline Vocational & & & -.061 & -.072 & -.056 & -.066 \\
\hline
\end{tabular}




\begin{tabular}{|c|c|c|c|c|c|}
\hline \multicolumn{6}{|l|}{ Educational Level } \\
\hline High School & & -.006 & -.007 & .010 & .009 \\
\hline$=<$ University & & -.083 & -.086 & -.062 & -.066 \\
\hline Tutoring Expenses & & .000 & .009 & -.016 & -.044 \\
\hline $\mathrm{D}-\mathrm{W}\left(\mathrm{d}_{\mathrm{U}}\right)$ & $2.076(1.876)$ & \multicolumn{2}{|c|}{$2.028(1.868)$} & \multicolumn{2}{|c|}{$1.991(1.898)$} \\
\hline $\mathrm{R}^{2}$ & .024 & \multicolumn{2}{|c|}{.013} & \multicolumn{2}{|c|}{.051} \\
\hline $\mathrm{F}(\mathrm{p})$ & $1.570(7,445)(\mathrm{p}=.142)$ & \multicolumn{2}{|c|}{$1.153(5,444)(\mathrm{p}=.331)$} & \multicolumn{2}{|c|}{$1.725(12,395)(\mathrm{p}=.059)$} \\
\hline K-S & $.772(.220)$ & \multicolumn{2}{|c|}{$.729(.306)$} & \multicolumn{2}{|c|}{$1.264(.179)$} \\
\hline B-P & $7.895(.005)$ & \multicolumn{2}{|c|}{$12.353(.030)$} & \multicolumn{2}{|c|}{$13.873(.309)$} \\
\hline$N$ & 446 & \multicolumn{2}{|c|}{445} & \multicolumn{2}{|c|}{396} \\
\hline
\end{tabular}

Education is not statistically significantly associated with either the first or current income of private tutoring recipients. Unlike the general population, education had no effect at all on this group, possibly because educational levels do not necessarily influence the income of private tutoring recipients. As other previous studies (Chai, 2007; Lee \& Kim, 2007) have indicated, with this particular group, it could be assumed that school ranking and name prestige have far more impact on this group's employment outcomes.

On the other hand, the father's educational level and employment type are statistically significantly associated with the income of private tutoring recipients. Like the general population, the father's education consistently showed direct and indirect association with his child's income. In fact, the father's education is statistically significant on income across all spectrums (first and current income, as well as general respondents and the private tutoring recipients). Like the general respondents, other social origin variables, i.e. the mother's educational level and household income and assets had no effect on the income of the privately tutored.

\section{Discussion and Conclusion}

The study investigated whether or not the association between social origin and/or education and labor market outcomes exists. Given the high rate of private tutoring, it tested the same predictors and their associations with the labor market outcomes of private tutoring recipients in order to investigate if the two groups showed any differences in their respective associations.

The findings reveal that unlike the assumption of the role of education in terms of income, the actual overall effect of education was weak among the general population group and had no effect on the privately tutored group. On the other hand, social origin consistently showed a significant effect in both groups, both directly and indirectly. Regarding Korea's case of the young adult population, the findings supported conflict theory more so than technological functionalism and human capital theory. These findings are also consistent with Yeo's study conducted in Korea which showed the strong direct effect of social origin in the young adult population's income, especially among 20 year olds. Among social origin components and regardless of private tutoring, the father's educational level consistently showed a direct and indirect association with his child's income. This finding is consistent with previous studies conducted in Korea (Choi \& Min, 2015; Han, 1997; Y. Kim, \& B. Kim, 1999; Yeo, 2008). In addition, the finding on the statistical significance of the prediction of the father's employment type, used as a substitute for class, on income is consistent with the arguments of conflict theorists. To add, the mother's education level and household income and assets are not predictors of income variance in Korean society, at least where young adult employees are concerned.

The study's results imply that conventional education indicators, tracking placement and educational levels no longer have an effect on one's income. As studies (Lee \& Kim, 2007; Park \& Kim, 2011) pointed out, the school's name, ranking, and quality could be a better predictor for income in a society where there is a very high rate of graduation from institutions of higher education. However, such stratification in the education system could be a reflection of the hierarchical labor market system. When the labor market is highly hierarchical, people adhere to the labor structure to obtain high status positions. To obtain high ranking jobs, students and parents are eager to not only increase the levels of education, but to enroll in prestigious 'top' universities, viewed as gateways to earning prestigious job positions. In order to send their children to the best universities, parents from the dominant group demand the establishment of more elite high schools from the government and seek to monopolize these schools by increasing their investment in their children's education, particularly in the consumption of private tutoring. Given the hierarchical structure and high competition in the labor market, it is inevitable that parents will invest in their children's education regardless of education's rate of return.

The hierarchical structure and high competition in the labor market also explains the study's finding that two- to three-year college graduates earn more than four-year university graduates or higher. A high-paying permanent 
position at a large company is considered the most prestigious job. However, due to slow economic growth, labor market conditions are not favorable, especially to young adults: A number of permanent positions for new hires in the larger companies have been reduced, while a number of temporary positions have increased. Accordingly, young adults with higher levels of education elect to continue their studies and spend more time on job preparation to acquire more desirable positions, while working part-time. Conversely, their counterparts prefer to hold a position immediately after graduation to avoid unemployment.

In Korea's case, it appears that the labor market has shaped the education system and strong parental beliefs in the role of education. The previous studies' assertion that the combination of increasing educational levels with decreasing inequalities in education across the population could lead to a reduction in overall income inequality may be true in some cases, but the assertion is not applicable to societies like Korea. The implication drawn from this finding is that, unlike their assumption, education may have a very limited role in the labor market.

Therefore, the study recommends that the first priority is building a consensus to strive for a less hierarchical culture and structure in the labor market and society at large. Furthermore, labor market policies that aim to establish a new labor market system of equal pay for equal jobs should then be linked to educational policies. Without efforts to amend the labor market structure and hierarchical culture, education reform, alone, would not be a remedy for solving the inequalities that exist in the labor market and cannot serve as a means of social mobility.

Lastly, I acknowledge that the study has methodological limitations in its data collection. For example, it is possible that the group of non-respondents could have included persons of lower incomes or socioeconomic backgrounds. Furthermore, among the initial respondents, there was a considerable decrease in their numbers within the labor market during the $10^{\text {th }}$ wave. Moreover, we may allow for the possibility that when the respondents reach mid-level positions in their respective careers, education effect may prove more apparent (higher R-squared) and education is positively associated with income. Despite any limitations, the study's results still reflect unique patterns in young adults' labor market outcomes in Korea. And based on the findings, it can be concluded that we may have exaggerated the role of education in the labor market (at least for young adults), as the utility side of education is echoed by human capital theorists and economists and in our acceptance of unchecked assumptions about the role of education.

\section{References}

Asplund, R., \& Barth, E. (2005). Education and wage inequality: An introduction to the national literature reviews. In R. Asplund, \& E. Barth (Eds.). Education and Wage Inequality in Europe: A Literature Review (pp. 1-56). Helsinki: Taloustieto Oy.

Becker, G. (1993). Human capital (3rd ed.). Chicago: University of Chicago Press. https://doi.org/10.7208/chicago/9780226041223.001.0001

Blau, P. M., \& Duncan, O. D. (1967). The American Occupational Structure. New York, NY: The Free Press.

Bowles, S. (1971). Unequal education and the reproduction of the social division of labor.” In A. H. Halsey, \& J. Karabel (Eds.). Power and ideology in education (pp. 137-153). New York: Oxford University Press.

Bowles, S., \& Gintis, H. (1976). Schooling in capitalist America: Educational reform and the contradictions of economic Life. New York: Basic Books.

Bray, M. (2001). Out-of-School supplementary tutoring. Childhood Education, 77(6), 360-366. https://doi.org/10.1080/00094056.2001.10521671

Bray, M. (2010). Shadow education: Comparative perspectives on the expansion and implications of private supplementary tutoring. Social and Behavioral Sciences, 77, 412-420. https://doi.org/10.1016/j.sbspro.2013.03.096

Bray, M., \& Lykins, C. (2012). Shadow Education: Private supplementary tutoring and its implications for policy makers in Asia. Manila: ADB.

Breen, R., \& Whelan, C. T. (1992). From ascription to achievement? Origins, education and entry to the labor force in the Republic of Ireland during the twentieth century. Acta Sociologica, 36(1), 3-17. https://doi.org/10.1177/000169939303600101

Chai, G. M. (2007). An analysis of the determinants of employment and wage of new college graduates. Korean Journal of Social Welfare, 59(4), 35-61. https://doi.org/10.20970/kasw.2007.59.4.002

Checchi, D. (2000). Does educational achievement help to explain income inequality? The United Nations University: World Institute for Development Economic Research Working Papers No. 208. Retrieved from 
https://www.wider.unu.edu/publication/does-educational-achievement-help-explain-income-inequality

Choi, P. S., \& Min, I. S. (2015). A study on social mobility across generations and inequality of opportunity. Social Science Research, 22(3), 31-56. Retrieved from http://www.dbpia.cokr/Article/NODE06527108

Cohen, J. et al. (2003). Applied multiple regression/correlation analysis for the behavioral sciences (3rd ed.) New York: Routledge.

Creswell, J. W. (2009). Research Design: Qualitative, Quantitative, and Mixed Methods Approaches (3rd ed.). California: SAGE Publications, Inc.

Crown, W. H. (1998). Statistical models for the social and behavioral sciences: Multiple regression and limited-dependent variable models. Westport: Greenwood Publishing Group.

de Gregorio, J., \& Lee, J. W. (2002). Education and income inequality: New evidence from cross-country data. Review of Income and Wealth, 48(3), 395-416. https://doi.org/10.1111/1475-4991.00060

Erikson, R., \& Jonsson, J. O. (1998). Social origin as an interest-bearing asset: Family background and labour-market rewards among employees in Sweden. ACTA Sociologica, 41(1) 19-36. https://doi.org/10.1177/000169939804100102

Han, D. D. (1997). The effects of parents' educational attainment, IQ, and high school education on later educational and socioeconomic attainment. Journal of Educational Research, 7, 1-27.

Hong, M., \& Cho, K. W. (2011). The graduation quota system and college premium. Korea Society of Economics, 29(3), 161-179.

Hosmer, Jr., D. W., Lemeshow, S., \& Sturdivant, R. X. (2013). Applied Logistic Regression (3rd ed.). New Jersey: Wiley \& Sons, Inc. https://doi.org/10.1002/9781118548387

Jang, S. S. (2001). Korean social mobility. Seoul: Seoul National University Press.

Jo, N. K. (2006). An analysis of changes to wage differentials by education in Korea (Unpublished master dissertation). Yonsei University, Seoul, Korea.

KEDI. (2007). Understanding Korean Education: Vol. 5. Education and Korea's Development. Seoul: KEDI.

KEDI. (2012). Korean Education at a Glance. Seoul: KEDI.

Kim, Y. H. (2000). Korea's education and society. Seoul: Education and Science Press.

Kim. Y. H., \& Kim, B. G. (1999). Education and social mobility during Korean industrialization. The Journal of Educational Research, 37(1), 155-172.

Kleinbaum, D. G., Kupper, L. L., Muller, K. E., \& Nizam, A. (1998). Applied regression analysis and other multivariable methods (3rd ed.). Belmont, CA, US: Thomson Brooks/Cole Publishing Co.

Lee K. H., \& Kim T. I. (2007). Gender, college rankings and majors, and earnings in Korea. Korean Journal of Educational Research, 45(3), 167-197.

Lee, H. D., Ihm, C. S., \& Min, K. S. (2010). Effects of coaching on college admissions. Journal of Economics and Finance of Education, 19(3), 151-175.

Lee, H. Y. (1993). The impact of social factors on university entrance student number. In G. S. Kim (Ed.), The sociology of education II: History, society, and education (pp. 311-349). Seoul: Education and Science Press.

Lee, J. W. (2011). Economics for inequality. Seoul: Humanitas.

Mastekaasa, A. (2011). Social origins and labour market success - Stability and change over Norwegian birth cohorts 1050-1969. European Sociological Review, 27(1), 1-15. https://doi.org/10.1093/esr/jcp050

Nam, J., \& Kim, S. (2013). Youth Employment and the Characteristics of NEET. Seoul: KLI

O'Connell, A. A. (2006). Logistic Regression Models for Ordinal Response Variables. Series in Quantitative Applications in the Social Science. Thousand Oaks: Sage Publications. https://doi.org/10.4135/9781412984812

Oh, O. H. (2000). Educational Fervor in Korean Society: Origin and acceleration. Seoul: Education and Science Press.

Osborne, J. W., \& Waters, E. (2002). Four Assumptions of Multiple Regression that Researchers Should Always Test. Practical Assessment, Research \& Evaluation, 8(2). Retrieved from 
http://PAREonline.net/getvn.asp? $\mathrm{v}=8 \mathrm{n}=2$

Park, C. N., \& Do, J. S. (2005). The effects of parents' socio-economic status on academic achievement. Social Welfare Policy, 22(August), 281-303.

Park, K. W. (2014). The college wage premium in Korea (1974-2011): A supply and demand factor decomposition. Review of Business and Economics, 27(1), 477-505. Retrieved from http://www.dbpia.cokr/Article/NODE02372234

Psacharopoulos, G., \& Patrinos. H. A. (2004). Returns to Investment in Education: A Further Update. Education Economics, 12(2), 111-134. https://doi.org/10.1080/0964529042000239140

Psacharopoulos, G., \& Woodhall, M. (1997). Education for development: An analysis of investment choice. New York: Oxford University Press.

Rubinson, R., \& Palph, J. (1986). Methodological issues in the study of educational change. In J. G. Richardson. (Ed.), Handbook of Theory and Research for the Sociology of Education (pp. 275-304). New York, NY: Greenwood Press.

Schultz, T. W. (1961). Investment in human capital. The American Economic Review, 51(1), 1-17. Retrieved from http://www.jstor.org/stable/1818907

Treiman, D. J. (1970). Industrialization and social stratification. Sociological Inquiry, 40(2), 207-234. https://doi.org/10.1111/j.1475-682X.1970.tb01009.x

Treiman, D. J., \& Yip, K. B. (1989). Educational occupational attainment in 21 countries. In M. L. Kohn (Ed.), Cross-national research in sociology (pp. 373-394). Beverly Hills: Sage publications.

Visser, P. S., Krosnick, J. A., \& Lavrakas, P. J. (2000). Survey research. In H. T. Reis, \& C. M. Judd (Eds.), Handbook of research methods in social and personality psychology (pp. 223-252). New York: Cambridge University Press.

Yeo, Y. J. (2008). A study of the influence of education on social mobility. Korea Institute for Health and Social Affairs, 28(2), 53-80.

\section{Note}

Note 1 . The study was partially adopted from my doctoral dissertation "Social Origin, Education, and Destination in Korea" conducted at GWU and published on August 30, 2015; however, a new examination of the association between social origin and income among those who received private tutoring was added to this study.

\section{Appendix A}

\section{Survey Questionnaire in KEEP}

- Which of the following best describes the work situation of your father?

(1) Permanent Wage Employee

(2) Temporary Wage Employee

(3) Employer (with at least one employee)

(4) Self-employed worker (without paid employees)

(5) Unpaid worker at a family member's workplace

- What is the highest level of education that your father (mother) has received? Or she or he is currently in school?

(1) Not in school yet

(2) Not currently studying

(3) Elementary

(4) Middle school 

(5) High school
(6) 2-3 year College
(7) 4 year University
(8) Graduate school (Master's degree)
(9) Graduate school (Ph.D)

- How much was the average monthly income of your household in the last year?:

Unit 10,000 won

- What are your family's financial assets, including the current value of your home, and the market value of all real estate, such as residential houses, buildings, forests, fields, land, etc?
(1) Less than $10,000,000$ won
(2) $10,000,000-25,000,000$ won
(3) $25,000,000-50,000,000$ won
(4) $50,000,000-75,000,000$ won
(5) $75,000,000-100,000,000$ won
(6) $100,000,000-200,000,000$ won
(7) $200,000,000-300,000,000$ won
(8) $300,000,000-400,000,000$ won
(9) $400,000,000-500,000,000$ won
(10) $500,000,000-1000,000,000$ won
(11) $1000,000,000-2000,000,000$ won
(12) 2000, 000,000-5,000, 000,000 won
(13) Over 5,000, 000,000 won

- $\quad$ During the last semester, from September 2003 to February 2004, how much did your household spend on the student targeted in this survey for private monthly educational expenses?

Unit 10,000 won

- What is your current educational background?
(1)
Middle school dropout
(2)
Middle school
(3) High school dropout
(4) High school
(5) 2-3 year College dropout
(6) 2-3 year College
(7) 4 year University dropout
(8) 4 year University
(9) Graduate school (Master's degree) dropout
(10) Graduate school (Master's degree)
(11) Graduate school (Ph.D) dropout
(12) Graduate school (Ph.D) 
- How much is your monthly average income?

Per month Unit 10,000 won

\section{Appendix B}

\section{Frequency Analyses}

Table B1. Income by Tracking Placement

\begin{tabular}{|c|c|c|c|c|c|c|c|c|c|c|c|c|c|}
\hline & & \multicolumn{4}{|c|}{ Special-purposed } & \multicolumn{4}{|c|}{ Vocational } & \multicolumn{4}{|c|}{ General } \\
\hline & & \multicolumn{2}{|c|}{ Men } & \multicolumn{2}{|c|}{ Women } & \multicolumn{2}{|c|}{ Men } & \multicolumn{2}{|c|}{ Women } & \multicolumn{2}{|c|}{ Men } & \multicolumn{2}{|c|}{ Women } \\
\hline & & $\mathrm{n}$ & $\%$ & $\mathrm{n}$ & $\%$ & $\mathrm{n}$ & $\%$ & $\mathrm{n}$ & $\%$ & $\mathrm{n}$ & $\%$ & $\mathrm{n}$ & $\%$ \\
\hline \multirow{8}{*}{ First Income } & $>100$ & 18 & 60.0 & 61 & 59.2 & 236 & 33.1 & 350 & 50.7 & 227 & 34.9 & 261 & 43.4 \\
\hline & $100-150$ & 6 & 20.0 & 19 & 18.4 & 296 & 41.5 & 299 & 43.3 & 202 & 31.0 & 216 & 35.9 \\
\hline & $150-200$ & 4 & 13.3 & 11 & 10.7 & 122 & 17.1 & 32 & 4.6 & 112 & 17.2 & 89 & 14.8 \\
\hline & $200-300$ & 1 & 3.3 & 10 & 9.7 & 51 & 7.1 & 8 & 1.2 & 86 & 13.2 & 29 & 4.8 \\
\hline & $<300$ & 1 & 3.3 & 2 & 1.9 & 9 & 1.3 & 1 & 0.1 & 24 & 3.7 & 6 & 1.0 \\
\hline & Mean & 94.47 & & 94.43 & & 118.39 & & 95.90 & & 128.46 & & 104.86 & \\
\hline & Total & 30 & & 103 & & 714 & & 690 & & 651 & & 601 & \\
\hline & $>100$ & 6 & 37.5 & 10 & 15.9 & 14 & 3.3 & 5 & 1.7 & 22 & 5.2 & 13 & 3.6 \\
\hline \multirow{6}{*}{ Current Income } & $100-150$ & 3 & 18.8 & 16 & 25.4 & 107 & 25.4 & 118 & 39.5 & 76 & 18.1 & 83 & 23.2 \\
\hline & $150-200$ & 5 & 31.3 & 17 & 27.0 & 165 & 39.1 & 130 & 43.5 & 140 & 33.3 & 143 & 39.9 \\
\hline & $200-300$ & 1 & 6.3 & 17 & 27.0 & 119 & 28.2 & 44 & 14.7 & 149 & 35.5 & 110 & 30.7 \\
\hline & $<300$ & 1 & 6.3 & 3 & 4.8 & 17 & 4.0 & 2 & 0.7 & 33 & 7.9 & 9 & 2.5 \\
\hline & Mean & 128.06 & & 160.54 & & 173.09 & & 154.44 & & 186.53 & & 175.26 & \\
\hline & Total & 16 & & 63 & & 422 & & 299 & & 420 & & 358 & \\
\hline
\end{tabular}

Unit 10000 (1 000 Won equivalent to 1 USD)

Table B2. Income by Educational Level

\begin{tabular}{|c|c|c|c|c|c|c|c|c|c|c|c|c|c|}
\hline & & \multicolumn{4}{|c|}{ High school } & \multicolumn{4}{|c|}{ 2-3 year College } & \multicolumn{4}{|c|}{4 year University or higher } \\
\hline & & \multicolumn{2}{|c|}{ Men } & \multicolumn{2}{|c|}{ Women } & \multicolumn{2}{|c|}{ Men } & \multicolumn{2}{|c|}{ Women } & \multicolumn{2}{|c|}{ Men } & \multicolumn{2}{|c|}{ Women } \\
\hline & & $\mathrm{n}$ & $\%$ & $\mathrm{n}$ & $\%$ & $\mathrm{n}$ & $\%$ & $\mathrm{n}$ & $\%$ & $\mathrm{n}$ & $\%$ & $\mathrm{n}$ & $\%$ \\
\hline \multirow{7}{*}{$\begin{array}{c}\text { First } \\
\text { Income }\end{array}$} & $>100$ & 91 & 33.7 & 241 & 49.2 & 231 & 29.5 & 342 & 44.8 & 112 & 41.8 & 23 & 46.9 \\
\hline & $100-150$ & 112 & 41.5 & 202 & 41.2 & 306 & 39.0 & 292 & 38.3 & 69 & 25.7 & 18 & 36.7 \\
\hline & $150-200$ & 44 & 16.3 & 31 & 6.3 & 152 & 19.4 & 93 & 12.2 & 35 & 13.1 & 5 & 10.2 \\
\hline & $200-300$ & 19 & 7.0 & 13 & 2.7 & 76 & 9.7 & 30 & 3.9 & 42 & 15.7 & 3 & 6.1 \\
\hline & $<300$ & 4 & 1.5 & 3 & 0.6 & 19 & 2.4 & 6 & 0.8 & 10 & 3.7 & 0 & 0.0 \\
\hline & Total & \multicolumn{2}{|l|}{270} & \multicolumn{2}{|l|}{490} & \multicolumn{2}{|l|}{784} & \multicolumn{2}{|l|}{763} & \multicolumn{2}{|l|}{268} & \multicolumn{2}{|l|}{49} \\
\hline & Mean & \multicolumn{2}{|l|}{94.47} & \multicolumn{2}{|l|}{94.43} & \multicolumn{2}{|c|}{118.39} & \multicolumn{2}{|l|}{95.90} & \multicolumn{2}{|l|}{128.46} & \multicolumn{2}{|c|}{104.86} \\
\hline \multirow{7}{*}{ Current Income } & $>100$ & 6 & 3.7 & 7 & 3.0 & 12 & 2.4 & 10 & 2.3 & 18 & 10.5 & 4 & 13.3 \\
\hline & $100-150$ & 51 & 31.1 & 89 & 37.7 & 103 & 20.2 & 112 & 25.7 & 31 & 18.0 & 9 & 30.0 \\
\hline & $150-200$ & 59 & 36.0 & 91 & 38.6 & 202 & 39.6 & 184 & 42.2 & 46 & 26.7 & 12 & 40.0 \\
\hline & $200-300$ & 42 & 25.6 & 44 & 18.6 & 163 & 32.0 & 121 & 27.8 & 63 & 36.6 & 5 & 16.7 \\
\hline & $<300$ & 6 & 3.7 & 5 & 2.1 & 30 & 5.9 & 9 & 2.1 & 14 & 8.1 & 0 & 0.0 \\
\hline & Total & \multicolumn{2}{|l|}{164} & \multicolumn{2}{|l|}{236} & \multicolumn{2}{|l|}{510} & \multicolumn{2}{|l|}{436} & \multicolumn{2}{|l|}{172} & \multicolumn{2}{|l|}{30} \\
\hline & Mean & \multicolumn{2}{|c|}{128.06} & \multicolumn{2}{|c|}{160.54} & \multicolumn{2}{|c|}{173.09} & \multicolumn{2}{|c|}{174.44} & 186.53 & & \multicolumn{2}{|c|}{175.26} \\
\hline
\end{tabular}

Unit 10000 (1 000 Won equivalent to 1 USD) 


\section{Appendix C}

\section{Preliminary Model Assessments}

Before proceeding with the statistical analyses, several assumptions were tested. First, the presence of multicollinearity among independent variables should be tested. This is because the presence of muticollinearity among independent variables could inflate the standard errors for the estimated regression coefficients, resulting in the decrease of the validity of statistical tests of these estimates (O'Connell \& Amico, 2006, p. 233). In this study, the mutlicollienarity was tested by a correlation coefficient matrix, Variance Inflation Factor (VIF), and Tolerance. It is generally accepted that collinearity does not cause problems when binaries' correlations are below .90 (Kleinbaum et. al., 1998). In addition, VIF is defined as $1 /(1$-Rsquared) and tolerance is calculated from 1/VIF. It is accepted that the VIF value and tolerance should be no larger than 10.0 and no less than 0.1 respectively (Kleinbaum etal., 1998). As shown in the below Table, there was no presence of multicollinearity among independent variables.

Table C1. Correlation Coefficient Matrix \& Multicollinearity Measures among Independent Variables

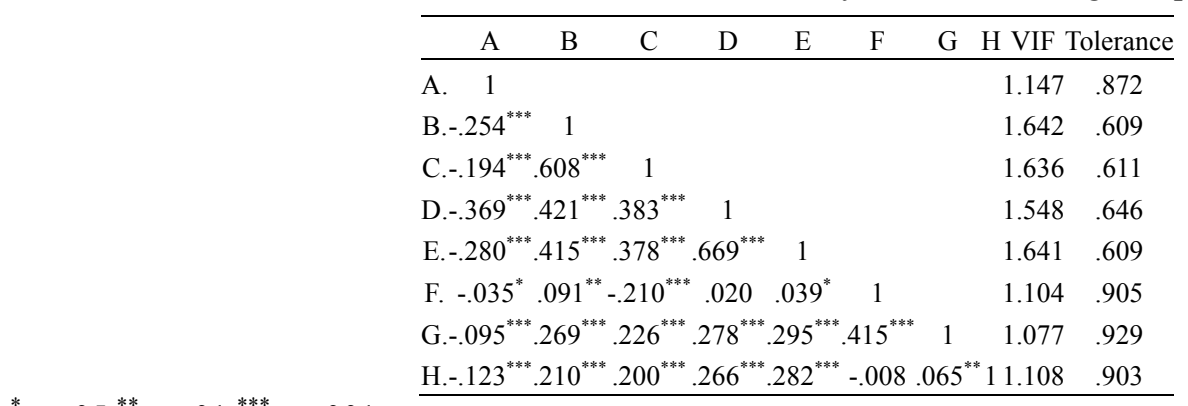

${ }^{*} \mathrm{p}<.05^{* *} \mathrm{p}<.01{ }^{* * *} \mathrm{p}<.001$

Note. A=Father's Employment Type; B=Father's Educational Level; C=Mother's Educational Level; $\mathrm{D}=$ Household Income; E=Household Assets; F=The Respondents' Tracking Placement; G=The Respondents' Educational Level; $\mathrm{H}=$ Private Tutoring Participation

The second assumption concerns linearity in the regression model: the relationship between dependent variables and each of the independent variables should be linear (straight line) (Cohen et. al, 2003, p. 117). In this study, the linearity was tested by examining residual plots. The distribution of the residual plots showed no evidence of a non-linear relationship.

The third assumption involves the normal distribution of data in multiple regression models. According to Osborne and Waters (2002), "Non-normally distributed variables (highly skewed or kurtotic variables, or variables with substantial outliers) can distort relationships and significance tests" (p. 3). In order to test the normality assumption in the multiple regressions, they suggested the visual inspection of data skew and kurtosis. In this study, the numerical measures of shape of skewness and kurtosis were tested to check the normality assumption. If either the skewness or kurtosis value is not close to zero, then the data set is not normally distributed. When the data is not normally distributed, then it is transformed into a $\log$.

\section{Copyrights}

Copyright for this article is retained by the author(s), with first publication rights granted to the journal.

This is an open-access article distributed under the terms and conditions of the Creative Commons Attribution license (http://creativecommons.org/licenses/by/4.0/). 